https://doi.org/10.4314/rjeste.v3i2.1

\title{
On-site and Off-site Effects of Soil Erosion: Causal Analysis and Remedial Measures in Agricultural Land - a Review
}

\author{
Félicien Majoro ${ }^{1 *}$, Umaru Garba Wali ${ }^{1}$, Omar Munyaneza ${ }^{1}$, François-Xavier Naramabuye ${ }^{2}$ and Concilie \\ Mukamwambali $^{3}$ \\ ${ }^{I}$ University of Rwanda, College of Science and Technology, Department of Civil, Environmental and Geomatics \\ Engineering, P.O. Box 3900, Kigali, Rwanda \\ ${ }^{2}$ University of Rwanda, College of Agriculture and Veterinary Medicine, P.O. Box 3971, Kigali, Rwanda \\ ${ }^{3}$ University of Rwanda, College of Education, Department of Mathematics, Science and Physical Education, P.O. Box \\ 55, Rwamagana, Rwanda
}

*Corresponding author: Felicien Majoro, Email: majoro.felicien@yahoo.fr, Cell phone: +250 788484054

\begin{abstract}
Soil erosion is one of the main factors causing land degradation. Furthermore, loss of soil nutrients ultimately causes worldwide reduction of agricultural productivity and water quality deterioration. Therefore, soil erosion control measures are required as an aspect of catchment management. The general purpose of this paper review is to make an overview of soil erosion throughout the world in order to highlight required studies on which to be based when proposing appropriate erosion control measures for agricultural fields. Different scientific documents including journal articles, internet materials, conference papers and books were used as research materials to achieve the objectives of the present work. This methodology enabled the researcher to make a synthesis of various researchers' views on this topic. Principally, this review focused on the effects and remedial measures of soil erosion. The research findings highlighted that soil erosion affects greatly the agricultural land, human properties and aquatic ecosystem. Both on-site and off-site effects are analyzed. Sediment transport in rivers resulted from soil erosion impacts on bridges, hydropower plants, water treatment plants and water bodies such as lakes and water reservoirs. The present review article strongly recommends the followings: (1) Performance improvement of the existing erosion control measures; (2) Promotion of new soil erosion adaptive measures; (3) Farmers trainings on Best Management Practices of soil erosion control and (4) Sensitization of governmental institutions and Non-governmental organizations (NGOs) to be extensively involved in soil erosion management.
\end{abstract}

Keywords: Erosion causes, erosion effects, erosion control measures.

\section{INTRODUCTION}

All over the world, wherever human being started the agricultural operations, there exists the problem of soil erosion in some extent. Spectacular examples of soil erosion are found due to excessive human activities which resulted into severe erosion problem.

Although soil erosion is a slow process in natural ecosystem, substantial serious effects like loss of top soil and effects on soil and water quality have been observed. Globally, eroded soil in flat land with grass cover and mountainous regions with normal vegetation cover amounts from 0.001 to $1 \mathrm{t} / \mathrm{ha} / \mathrm{year}$ and from 1 to 5t/ha/year respectively (Pimentel \& Kounang, 1998). Soil erosion has resulted in a huge deposition of soils with large deltas associated to Nile, Ganges and Mississippi Rivers (DeVere, 2010). 
The total earth surface area is 510.1 Million $\mathrm{Km}^{2}$ and the earth surface area covered by land is about $29.2 \%$ while $70.8 \%$ is covered by water. Approximately $50 \%$ of the earth's land is devoted to agriculture (Zuazo \& Rodriguez, 2008) while 75 billion tons per year of fertile soil is lost from agricultural land due to erosion (DeVere, 2010). The global soil erosion is 13 to 40 times faster than the natural soil replenishment (Pimentel, 2006; Zuazo \& Rodriguez, 2008).

Agricultural land of developing countries is prone to erosion effects because of poor farming techniques and lack of financial means for their farming systems to replace lost soils and nutrients. Pimentel and Michael highlighted that about $99.7 \%$ of human food is produced from land while less than $0.3 \%$ comes from aquatic ecosystems and this indicates the need of huge food supplies for future generations (Pimentel \& Michael, 2013). Farming and other economic activities in these areas have become environmentally unsustainable causing on-site and off-site effects.

Rainfall is the major cause of soil erosion which is responsible to remove soil to a new place of deposition through runoff process (Sakinatu \& Muhammad, 2017). On the basis of causes of soil erosion, it can be classified as erosion by gravity, water splash, interrill, rill, gully and streambank erosion due to the action of flowing water (Madhu, 2008). The two main types of soil erosion are geological and accelerated soil erosion. Compared to soil formation, the geological soil erosion occurs at the same rate while the accelerated soil erosion has a very high rate. Known as a natural geomorphologic process, soil erosion is strongly linked to water and land interactions but highly influenced by different human activities to be an environmental hazard (Farayi, 2011).

The main on-site effect of soil erosion is the reduction of soil quality (nutrient loss and decrease in water holding capacity) which significantly leads to the reduced soil productivity (Lal, 2001). In the USA, 3 million hectares of agricultural land becomes unproductive annually due to erosion (El-Swaify, Dangler \& Armstrong, 1982).

Sediment in rivers is composed mainly by eroded soil and associated pollutants from agriculture and its impact on socio-economic development projects along the river course constitutes the main off-site effect of soil erosion.

In many developed countries, the best management practices (BMPs) for soil erosion management have been technologically implemented. These techniques helped greatly to meet the tolerable soil loss criterion (Sakinatu \& Muhammad, 2017). T-value is a concept used to judge if a soil has a potential risk of erosion (Liu et al., 2010).

Throughout the world, many investigations have proposed the soil loss tolerance ranging from 5 to 11.5 t/ha/year (Lal, 1994; Bagarella, Lazzarin, \& Noro, 2015; Wischmeier \& Smith, 1978). By compiling all these different research views, the generally accepted soil loss tolerance is $5 \mathrm{t} / \mathrm{ha} / \mathrm{year}$.

In this review, various causes and effects are analyzed. Furthermore, best management practices are assessed as remedial measures to reduce on-site and offsite soil erosion effects to tolerable rates.

\section{METHODOLOGY}


For the successful completion of this work, the researcher gathered different materials for the research and summarized the characteristics of the most relevant causes, direct and indirect impacts and remedial measures of soil erosion in agricultural land. Journal articles, conference papers, books, internet materials have been read in order to gain general ideas to this review. This methodology enabled the researcher to make a synthesis of various researchers' views on this topic.

\section{SOIL EROSION APPLICATION MODELS}

To guess the actual status of soil erosion for establishing the best erosion management plans, many models have been developed and used.

\subsection{Universal Soil Loss Equation (USLE)}

Universal Soil Loss Equation (USLE) is soil erosion model which is the most widely accepted method for estimating the annual soil loss. It has been originally proposed in 1958 and actually modified to its present form in 1978 by Wischmeier \& Smith.

The empirical equation of this model is as follows:

$A=K * R *(L S) * C * P$

Where:

Average annual soil loss $A$ (t/ha*year); Soil erodibility or $K$-factor (ton*ha*hr/ha*MJ*mm); Rainfall erosivity or $R$-factor $\left(\mathrm{MJ}^{*} \mathrm{~mm} / \mathrm{ha}{ }^{*} \mathrm{hr} * \mathrm{yr}\right)$; Slope length factor or $L S$ - factor (Dimensionless); Crop management factor or $C$-factor (Dimensionless); Erosion-control practice factor or $P$-factor (Dimensionless).

Compared with other models, Universal Soil Loss Equation is a familiar model used to quantify soil erosion because of less data demand (Renard et al., 1997) but its applicability is limited to sheet and rill erosion without any consideration of gully erosion.

\subsection{Modified Universal Soil Loss Equation (MUSLE)}

In 1975, Williams developed MUSLE as soil erosion estimation model. It helps greatly in stream sediment yield estimation with individual storms events. As written below, the Modified Universal Soil Loss Equation is similar to the Universal Soil Loss Equation in which the rainfall factor is replaced by runoff factor.

$Y=11.8 *(V q * Q p)^{0.56} * L S * C * P$

Where: $Y$ represents the sediments yield for a single event in tons; $V q$ indicates the volume of runoff in $\mathrm{m}^{3}$ which is estimated using the USA Soil Conservation Services (SCS) curve number method; $Q p$ is the peak discharge in $\mathrm{m}^{3} / \mathrm{s}$ which is estimated using the rational method; while $K, L S, C$ and $P$ denote the same parameters as those in the USLE model. 


\subsection{Revised Universal Soil Loss Equation (RUSLE)}

RUSLE is considered as a version of USLE. Implemented using a computer program with an in-built database, RUSLE model is suitable for application in the USA. Even though RUSLE offers several modifications in the USLE aimed at better estimation of the soil loss, it is not very popular and the inbuilt database is US centric which limits also its applicability in other regions of the world (Renard et al., 1997).

\subsection{The Soil-Loss Estimator for Southern Africa (SLEMSA)}

Originated in Zimbabwe, the SLEMSA model is used to quantify the amount of soil eroded annually due to sheet erosion after long period of time (Bonda et al., 1999). The idea of formulating SLEMESA was developed based on USLE model. The SLEMSA model categorizes the soil erosion variables into four physical systems: crop, climate, soil and topography. The three sub-models (Bare soil sub model, topographical sub model and crop sub model) are accordingly deduced from these control variables. The equation below expresses SLEMESA model:

$Z=K * C * X$

Where $Z=$ the mean annual soil loss (in tons* ha),

$K=$ Erodibility Factor (tons/ha*yr),

$X=$ Topographic Factor and $C=$ Crop factor.

Considering the model advantages, it is most applicable in developing countries (Shahzeidi et al., 2012).

\subsection{The FAO Model (FAO, 1979).}

The basic purpose of FAO model was to assess the rate of soil erosion caused by water over large extent area using relative magnitudes of the effect of each variable. The FAO model combines the methods for assessment of land degradation in its forms as well as wind erosion, salinization, acidification, sodication and toxicity. As a basis of maps at a large scale, this model was used to show the situation of northern African land degradation. The Equation below represents FAO model and its symbols with the same meaning in USLE.

$A=R * K * S * C$

Eq. (4) 
The only difference with USLE is that FAO model was not tested against the rate of soil erosion.

\subsection{Morgan-Morgan-Finney Model}

The Morgan-Morgan -Finney model is used to predict yearly soil loss from hill slopes and it estimates soil loss by considering two phases such as water and sediment phases. Sediment phase occurs when heavy rain drops are detaching soil particles, transporting due to runoff generated and depositing them. In water phase, the intensity of rainfall and amount of runoff are estimated from annual rainfall data (Morgan, Morgan \& Finney, 1984).LAND USE AND SOIL EROSION

\subsection{Climate and Soil erosion}

Global warming is known to affect strongly hydrological cycle with a direct consequence of declining rainfall levels in many places while evaporation and transpiration rates are projected to increase, with more intense events such as droughts. These changes may reduce the availability of soil moisture for plant growth. The powerful factor which increases soil erosion rate is the rain fall amount and its intensity. (Nearing \& Pruski, 2004).

\subsection{Human Activities Affecting Soil Erosion}

There are two main causes of soil erosion including human activities considered as the main accelerating factor of soil erosion and geological phenomena linked with natural erosion affecting the earth surface (Guo et al., 2018).

The result of disturbing the soil during excavation works for constructing activities, mining and tillage practices for agriculture is to weaken the top surface which leads to excessive soil erosion.

Deforestation for logging or household fire woods is another way in which humans cause soil erosion. Deforestation and overgrazing are the removal of the ground cover leaving the soil unprotected against soil erosion phenomena (Joyce, 1998).

Overgrazing occurs when farmers stock too many animals such as sheep, cattle or goats on their land. The animals damage the soil surface by eating the vegetation and either digging into wet soil or compacting dry soil with their hooves. This can prevent grass growing and slow down the percolation of water through the soil.

Statistically, the most important factors which influence soil erosion are population density and land tenure which govern the types of land use and degree of pressure on the land.

\subsection{Impact of Erosion on Soil Productivity}

\subsubsection{Soil seal and crust development}

Surface crusts and seals formed from different processes especially physical and biological process, have the ability to change volume of runoff and eroded soil, particularly in region covered by low land cover (Bradford \& Huang, 1993). 
Many studies have shown that the formation of crust is the main cause of soil erosion because it reduces infiltration and water storage in soil and increase runoff which in turn promotes soil erosion (Bradford \& Huang, 1993; Robinson \& Phillips, 2000).

\subsubsection{Soil loss in agricultural lands}

Soil erosion reduces agriculture productivity and soil fertility. In some region of the world, problems of insufficient land for cultivation rise due to the population growth and soil degradation that cause long term effects to human health (FAO, 2019).

It is reported that 15 million of tons of soil per year is lost, which is causing a loss of greater than 1 million US\$ (FAO, 2019).

\subsubsection{Nutrients losses from soils}

In case of high rated soil erosion events, the removed nutrients (nitrogen phosphorus, potassium, calcium, etc.) are 3 times more than nutrient particles remaining in the soil (Narendar et al., 2017). The estimated proportions of top soil nutrients removed ranged as follow: 1 to $6 \mathrm{~kg}$ of nitrogen, 1 to $3 \mathrm{~kg}$ of phosphorus, and 2 to $30 \mathrm{~kg}$ of potassium, whereas the topsoil on the eroded land has an average nitrogen content of only 0.1 to $0.5 \mathrm{~kg}$ per ton (Landgale et al., 1992). If nutrients are lost at high level, more fertilizers must be applied to standardize the original soil nutrients composition. Nutrients required to restore degraded land are mainly nitrogen and phosphorus combined with calcium, magnesium and potassium (Berthol et al., 2003). To restore nutrients released due water erosion, it is required both chemical and organic fertilizers but it is very expensive to the poor farmers and nations. Not only economic problems but also the fertilizer inputs have huge harmful impacts on human health and pollute the soil, water and air. Proper management should be taken instead of restoring degraded soil.

\subsubsection{Soil erosion and crop yield.}

Most of soils suffer for yields due to the degradation of physical and chemical composition of the soil. Those impacts occur cumulatively and long- term due to successive soil erosion events. Most of studies discuss the consequences of soil erosion on the crop yield but there are no exact results discussing the relationships which indicate yield reduction against certain erosion rates (Littleboy et al., 1996). Soil erosion affect crop yield and loss of arable land areas due to earth fall from landslides and channels formation within the arable areas. Soil productivity varies from one crop to another.

The researchers in Europe tried to relate Soil Water Available to crop yields. At 300 sites, experiments showed the following results: the crop yield varies between 1.43tons/ha/year to 9 tons/ha/year in case of negligible soil erosion rates while a decrease of $1 \mathrm{~mm}$ of soil water available to plant imposes a decrease in crop yield of $47 \mathrm{~kg} / \mathrm{ha} / \mathrm{yr}$. It is reported that Europe has developed sufficient erosion control measures and agriculture productivity will be satisfactorily improved (Bakker et al., 2007). 
In North America, erosion reduced crop products as follows: $234.5^{*} 10^{3}$ tons/year reduction for maize, $60.2 * 10^{3}$ tons/year for soybeans, $75.0^{*} 10^{3}$ tons/year for wheat and $1.9 * 10^{3}$ tons/year for cotton. Approximately U.S.\$37.9 million in the United States and \$41.2 million in North America were used in soil erosion control per annum (Christoffel et al., 2000).

\section{SEDIMENT TRANSPORT AND ITS IMPACTS ON SOCIO-ECONOMIC DEVELOPMENT PROJECTS}

\subsection{Sources and Types of Sediment in Rivers}

Globally, soil erosion increases the amount of sediment transported in rivers at a rate of 2.3 billion tons per year (Syvitski et al., 2005).

Sediment sources in any given watershed vary with location and time. In general, sediment sources can be divided into two broad categories: (1) upland sediment sources, and (2) channel sediment sources. Upland sediment sources include various land-use and land-cover types: forest, cropland, pasture, construction sites, roads, etc. Channel sediment sources can include the stream banks, beds, flood plain, and gullies. It is important to separate sediment derived from uplands versus sediment generated from channels because sediment reduction strategies differ by source and require different management approaches. Rivers are the main conveyors of eroded sediments to the sea.

The total sediment load in rivers is mainly classified into 3 types: bed load, suspended load and saltation load materials. The suspended materials are typically clay and silt sized materials and are often referred to as "fine-grained sediments" transported in suspension due to turbulence while bed load materials are seen as coarse-grained sediments transported on the bottom of the river and which are dominated by sand and gravel.

Saltation load is a transitional state between bedload and suspended load. Saltation load refers to particles that are light enough to be picked off the river bed by turbulence but because they are too heavy to remain in suspension, they sink back to the river bed.

\subsection{Sediments Transport Mechanism}

Sediment transport refers to the sediment movement in a stream or river. The material eroded from the river bed is referred to bed load and suspended load material. Coarse sediments (cobbles, gravel and coarse sand) are carried by the flow as bed load close to the bed surface. Fine sediments (medium and fine sand materials) are kept in suspension by the water turbulence for a distance that depends on sediment grain size, turbulence and relative gravity.

The very fine materials originating mainly from soil erosion (due to rain, landslides, debris and mud flows) and from the falling of cohesive river banks are made of silt and clay known as wash load materials (Colby, 1957). These materials are generally transported as suspended load by the water turbulence and as colloidal suspension.

\subsection{Impacts of Sediment Transport on Rivers and Drainage Channels}

Referring on the transport capacity of the flow, sediment is picked up or deposited. Rills are 
widened and deepened to gullies, stream banks are undercut. Ditches and bridges are damaged (Schwertmann et al., 1996).

\subsection{Impacts of Soil Erosion on Bridges Piers}

Bridges are structures constructed to carry smoothly road traffic for easy passing of physical obstacles like rivers, lakes, valley. Their piers are constructed mainly in the riverbed or alluvial sediments which is the main cause of scour through the movement of water with abrasive materials. Scour can be classified as contraction and degradation scour which occurs when water accelerates as it flows through an opening that is narrower than the channel upstream from the bridge. Over long periods of time, degradation scour either on upstream or downstream can result in lowering of the stream bed (Julien, 2011).

\subsection{Impacts of Soil Erosion on Rivers, Lakes and Water Reservoirs}

Most of aquatic habitats are destroyed by eroded soil from watershed (construction and mining sites, agricultural fields, etc.). The eroded soil flows in stream, rivers or into lake and water reservoirs with a lot of quantity of chemicals and heavy metals where it causes excess turbidity and water eutrophication that harms aquatic life and makes the water less useful for domestic use and recreation (Bing et al., 2013; Wilson, Cullum \& Romkens, 2008; Zhai, 2010).

\subsection{Impacts of Soil Erosion on Water Treatment Plants (WTPs)}

Water pollution is caused mainly by run off as when it flows, it collects pollutants such as oil, pesticides, sediments, bacteria, and other chemicals, and then deposits them into waterways and may alter aquatic life and make waterways toxic to human life. Aquatic ecosystem nutrients create water treatment problems ( $\mathrm{Lu}, \mathrm{Lo} \& \mathrm{Hu}, 1999)$. Soil erosion can create negative impact on water quality and aquatic ecosystems due to the high concentration of sediments and associated nutrients from land into water bodies. The effects of sediments load on the performance of a water treatment plant are: high turbidity, high cost of coagulants to be used in water treatment, low quantity of water to be supplied, damage of valves and taps, filters blockages and stoppages from working effectively, fills of tanks and pipes with mud and silt and it can also be causing the delay in water treatment process.

\subsection{Impacts of Soil Erosion on Hydropower Plants (HPPs)}

During rainy season, a large quantity of sediment related to soil erosion reduce the performance of hydropower plants by reducing the total energy production by $7 \%$ annually (Goudie, 2000).

Sediment can lead to significant damages of hydropower turbines and other mechanical equipment as a result of the breakdown of the oxide coating on the blades, and leading to the total cut-off of the plant with the needs of replacement of damaged materials (Munyaneza et al., 2015). Rwandan hydropower plants which draw their water from Sebeya river face heavy impacts of sediment related to erosion. Keya and Gisenyi HPPs are runoff river projects facing different issues of sedimentation. Sediment flows with hard and abrasive materials from Sebeya river are the main leading cause to damages on hydropower turbines during heavy rainy season (Munyaneza et al., 2015). 
Erosion control within the watershed of a hydropower dam would mitigate the impacts of sedimentation by reducing the volume of sediment that is brought to the dam by the river (Morris \& Fan, 1998). There are only two methods of reducing the amount of sediment that enters a reservoir: either to implement erosion control measures or trapping eroded sediment before it reaches the reservoir.

\section{BEST MANAGEMENT PRACTICES OF SOIL EROSION CONTROL}

Erosion control is any action of preventing or controlling wind or water erosion to protect soil surface particles from being detached by soil erosion agents.

Numerous soil erosion control techniques, including soft and hard best management practices (BMPs) have been associated with promising benefits and efficient performance when applied in agricultural fields.

\subsection{Soft BMPs}

\subsubsection{Mulching}

Mulch is any layer of material applied to the surface of soil to protect the soil from the erosion and evaporative effects of wind and sun. Mulch can be organic, inorganic or plastic: Mulch can be plant material, like straw and wood chips or it can be gravel or non- living material like recycled glass, cinders, decorative rock, and recycled rubber. In addition to erosion reduction, mulch increases water holding capacity of soil by reducing compaction. It increases infiltration by slowing runoff and giving it more time to soak into the soil by reducing erosion from bare soil and supply nutrients and organic matter to the soils. Mulching helps in controlling moisture content of the soil and temperature fluctuations, improves soil properties such as the addition of the soil nutrients which result in an increase of the crop yield. Mulching increases the crop yield by 50-60 per cent under rain fed situations and it is a best way of achieving food security sustainably (Patil, Kelkar \& Bhalerao, 2013).

\subsubsection{Cover crops and vegetation.}

Cover crops increases soil health, improves soil structure and reduces the need for costly inputs such as fertilizer and mechanical tillage. Cover crops protect water quality by slowing erosion and runoff and increase water infiltration and retention. If trees are removed, open land become erosion prone areas at high extent. Soil surface is protected by vegetation from raindrop impact which acts as a detachment agent of soil particles. Franz et al. (2018) noted that vegetation is the most common natural element used to control the erosion as it aids in protecting the soil and preventing the erosion by absorbing water that the soil is unable to hold and also by hindering the wind that might blow off the topsoil. The vegetation can reduce the soil erosion rate by 90\% (Franz et al., 2018). A series of laboratory flume simulation experiments have shown that vegetation could reduce the mean velocity by $31-65 \%$ (Pan \& Shangguan, 2006). Researchers also found that the average runoff and sediment reductions were $51.02 \%$ and $32.22 \%$ for soil with vegetation respectively (Bai et al., 2019).

In addition, trees and shrubs can acts as soil stabilizer by ensuring the soil stability and the continuity of agricultural activities. 


\subsubsection{Protective grasses on river banks}

Bank erosion mostly occurs in rivers and depends on frequency and magnitude of water forces. Human activities (sand mining, infrastructure building, artificial cutoffs and land use alterations or removal of vegetation, change the river morphology and natural dynamics of rivers) influence the processes of erosion by sediment transport and deposition along the river corridor.

Protective grasses increase the resistance of stream banks to erosion and play an important role to fish and wildlife populations and contribute to an aesthetic view of the riverbanks. Grassed water ways have the ability to traps suspended sediments at rate greater than $90 \%$ (Fiener \& Auerswald, 2003).

\subsubsection{No tillage method}

In zero tillage, the land for crop cultivation is left undisturbed from harvest to planting or not ploughed at all while in the case of minimum tillage, just holes for planting are made and only at the places where the crop is going to be planted or grain sown.

A combination of no-tillage with crop residue mulch is more effective in runoff and erosion control.

\subsubsection{Buffer zones}

Buffer zones increase the capture of sediment and organic material. It is revealed that buffer zones increased the trapping of sediment and infiltration from 10 to $90 \%$ respectively (Matthew et al., 2007). Vegetated buffers decrease the runoff velocity of water. They are experienced to have a high sediment trapping efficiency (Matthew et al., 2007).

\subsection{Hard BMPs}

\subsubsection{Terraces}

When the rain falls, a part of water infiltrates into the soil surface and the remaining flows as a runoff downhill until it reaches natural zones of deposition.

Terraces are mechanical structures such as an earthen ridge or a stone wall which reduces the slope steepness and divides the slope into short gently sloping sections. Terraces reduces the runoff velocity and soil loss, increase the soil moisture content through improved infiltration, reduce evaporation and can be created to divert runoff to a prepared or safe area for minimizing the effects of erosion to a tolerable level (FAO, 2000).

Regular inspections of terraces especially after large storm events are recommended in order to increase their performance (William, 1997). Terraces are more favorable in agricultural land with steep slopes ranging from $16 \%$ to $40 \%$ with high erodibility factor and not in sandy and coarse soil (IWRM, 2016). It is shown that terracing reduces soil erosion up to $99 \%$ (Bai et al., 2019). 
Terracing is one of the oldest methods of erosion control and nowadays it is used as best management practice for soil and water conservation all over the world but it is a more expensive soil conservation practice (IWRM, 2016).

\subsubsection{Contour Bunds}

As progressive terraces, contour bunds are suited to flat areas of slopes less than 16\% (IWRM, 2016). According to the workshop report compiled by Savadogo, Bayala \& Kalinganire (2017), it is reported that the contour bunds can reduce the soil erosion and increase the soil water holding capacity in the intervention area. As an example, the yield for a maize farmland under contour bund management increased from 35\% to $38 \%$ while for millet and sorghum, the yield increased from $30 \%$ to $60 \%$ (Savadogo, Bayala \& Kalinganire, 2017).

\subsubsection{Check Dam}

Check dams are structures constructed across a channel or a river to lessen water velocity and to catch sediments (Gray \& Leiser, 1982).

The experiment conducted by Pravat, Ramkrishna \& Gouri in 2013 has revealed that check dams performance may reach up to $50 \%$ sediment reduction when used properly.

\subsubsection{Anti-erosive ditches}

An anti-erosive channel is a drainage channel constructed to prevent runoff water from upper hill to enter to a cropped land. In this channel, water may infiltrate or may be diverted. To increase the performance of anti-erosive ditches, protective grasses are planted on ridges along the channels and the collecting drain should not slope less than $1 \%$ lengthwise in order to reduce the scouring effect of high flow velocity. Like other erosion control structures, regular maintenance is required to keep the channeling capacity of the drainage ditches (Kuypers, Mollema \& Topper, 2005).

\subsubsection{Grassed waterways}

Grassed waterways are more important in filtering by retaining runoff sediments, pollutants and other particulate matter within storm water and their performance will depend on soil permeability within the area. According to the study conducted by Fiener \& Auerswald in 2003, the runoff and sediments were reduced by $90 \%$ to $10 \%$ and by $97 \%$ to $77 \%$ respectively.

\subsubsection{Hillside water ponds}

Rainwater harvesting is a system of collecting water through different techniques such as storage of rainwater on surface reservoirs and groundwater recharge for future use.

The research conducted in Bugesera District of Rwanda showed that $88.89 \%$ of farmers adopted the use of hillside water ponds in agriculture fields, their life standard has been both economically and healthily improved (Munyaneza et al., 2016). In addition, the study conducted in China (2011) 
revealed that the use of ponds for retaining rainwater reduced soil erosion up to $15.9 \%$ (Peng, Yonggang \& Yongming, 2011).

\subsubsection{Riverbank stones revetment: use of riprap and gabions}

The revetments are applied to protect riverbanks from erosion and piping collapses which would be caused by strong river current. The gabions are used in civil engineering for earth retention and erosion control. Gabions promote growth of vegetation and consequently reduce erosion (Morgan, 2005; Saleem, Zahoor \& Shakeel, 2018). The shear strength of the soil behind the gabion revetments increase in 6 to 12 months after construction by $59.6 \%$ and $162.9 \%$, while the shear strength of the soil under riprap increased by $115.6 \%$ and $239.1 \%$ respectively. The results also indicated that the gabion and riprap revetments could increase the river water purification costs and the ecological biodiversity in the region (Van et al., 2018).

\subsubsection{Retaining walls made of gabions for slope stabilization}

Retaining walls are structures made of masonry, stone, brick, concrete or a combination of these. They are used to support soil laterally from a building or any other structure and they may be used also as erosion control structure. They are mainly used where the toe of slope can collapse and the slope failure is likely to progress upward along the slope.

Based on the type of materials, gabions are rectangular metal cage fabricated from a hexagonal mesh of galvanized steel wire filled with natural stones. Comparatively to other retaining walls, the main advantage of gabions retaining walls, is to reduce the runoff velocity or to increase the stability of sloping surface area with seepage problems. Their implementation is easy, economically and flexible and they can be vegetated (William, 1997).

\subsubsection{Sediment basin or catch basin}

A sediment trap or sediment basin is an earthen embankment constructed across a waterway with a spillway made of stones or aggregates to slow the evacuation of runoff by retaining it for a short period of time which allow the settlement of sediments. Sediments basins remove mainly silts but will not remove fine silts and clay (William, 1997).

\subsubsection{Constructed wetland}

Permeable soils are not suited for constructed storm water wetlands. Constructed wetlands improve water quality: Constructed wetlands showed a good performance on removal of the total suspended solid and ammonia with $70 \%$ and $76 \%$ respectively (Zhang, Richard \& Tan, 2009).

\subsubsection{Sediment fences}

Sediment fence is a structure which acts as a barrier of sediment or constructed to retain the soil or sediment from disturbed land by settling until the activities disturbing the land are sufficiently completed to allow revegetation. 
Researches showed that sediment fences reduce effluent total suspended solids (TSS) and turbidity ranging from $88.2 \%$ to $98.4 \%$ and from $49.2 \%$ to $92.8 \%$ respectively (Troxel, 2013).

\subsubsection{Use of paved block as energy dissipaters}

Paving blocks are used for reducing the runoff velocity depending on paving types. Each type of paving blocks has different performance in reducing the flow velocity. The surface runoff velocity reduction using paving blocks is generally above 40\% (Laksni et al., 2017).

\subsubsection{Roof runoff and cisterns}

Rainwater harvesting is more important as it reduces surface runoff which is the main cause of soil erosion, flooding and destruction of socio-economic infrastructures. It is reported that the use of roof runoff cisterns reduces soil erosion by $98 \%$ (Calfoforo et al., 2009).

\subsection{Limitative factors on the implementation of soil erosion control measures}

\subsubsection{Social constraints}

The farmers need trainings on implementing the best management practices of soil erosion control due to the fact that the majority of farmers have a low educational level and trainability. The poor knowledge about the benefits of soil and water conservation (SWC) could be the limiting factor to adopt such erosion control measures (Okoba \& De Graaff, 2005; Debebe et al., 2013).

\subsubsection{Economic constraints}

Most of SWC techniques (terraces, contour bunds, retaining walls, check dams, sediment basins, etc.) are costly to build.

Many researchers reported that the limiting factors of the adoption of soil and water conservation techniques are related to poverty and limited knowledge (Bizoza \& De Graaff, 2012; Bidogeza, 2007; Barbier, 1990).

\subsubsection{Institutions constraints}

The institutions constraints on implementing soil protection measures were that subsides from Government and Non-Government institutions are to support a limited number of farmers. Seeds and fertilizers reach farmers over time and lack of farmers trainings on utilizing soil conservation measures is also a limiting factor. It is confirmed that sharing knowledge among farmers and training could enhance adoption of bench terraces and anti-erosive ditches (Bizoza, 2011).

\subsubsection{Government responsibility in improving farming system}

To cope with the problem of soil erosion, the government of Rwanda set a long-term program of transforming agriculture that includes conservation of soils, reducing soil erosion and restoring soil fertility (MINAGRI, 2009). It is reported that the government support led to the adoption of soil 
conservation techniques in in Ethiopia (Kassa et al., 2013). This was furthermore supported by the findings of (Mgbenka et al., 2012) who reported about the government support to farmers to adopt $\mathrm{SWC}$ techniques in Nigeria.

The government responsibilities in improving farming are farmers trainings and mobilization of a specialized technical team to assist in implementation of soil conservation measures, generalizing the application of fertilizers and to facilitate farmers access to microfinance credit. The research showed that farmers without knowledge about a practice cannot be expected to adopt it unless they understand its expected costs and benefits (Solomon, 2016).

\section{CONCLUSION}

Worldwide, soil erosion is a major environmental problem. It is one of the environmental phenomena to which the adage "Prevention is better than cure" is most applicable. For the goals of best management practices to be achieved, all stakeholders can participate in setting out of policies, rules and regulations with their implementation to reduce and manage the soil degradation rate in their country. A lot of researchers should focus their attention on catchments management measures that can be easily applied by the indigenous knowledge to fight against the occurrence of soil erosion. Water quality improvement is also an environmental concern which needs a strong support and participation from the residents and government.

Increasing vegetation cover of soils in this climatic change-driven 21 st century characterized by increased incidences of rainfall is very expedient so as to reduce the power of rainfall to induce soil erosion. To this end, laws for afforestation and against deforestation should be erected by governments with provisions to punish offenders adequately.

Prioritizing dry season farming becomes necessary to avoid more disturbance of soils during rainy period which would predispose them to the impact of raindrops and runoff that detach and transport soil particles in splash-sheet-rill-gully erosion processes.

All affected people (landholders, farmers, etc.) should be empowered through grants from governments, donor agencies and non-governmental organizations (NGOs) to adopt and implement erosion control measures at an early stage.

Trainings and sensitization in soil erosion management should eradicate all agricultural practices that uncover the soil and expose it to the erosive power of rainfall.

\section{ACKNOWLEDGEMENTS}

The authors are grateful to the University of Rwanda (UR) for its support and wish to acknowledge the support of UR SWEDEN PhD PROGRAM in sponsoring this research. We cannot fail to commend and appreciate the work of various authors used for the review. 


\section{REFERENCES}

Bagarella, G., Lazzarin, R., \& Noro, M. (2015). On the activation strategy of the chiller in waterloop self-contained refrigeration system: An experimental analysis. International Journal of Refrigeration, 57, 94-102.

Bai, J., Shengtian, Y., Yichi, Z., Xiaoyan, L., \& Yabing, G. (2019). Assessing the impact of terraces and vegetation on runoff and sediment routing using the time-area method in the chinese Loess Plateau. Water, 803(11), 1-20, doi:10.3390/w11040803.

Bakker, M. M., Govers, G., Jones, R. A., \& Rounsevell, M. D. A. (2007). The effect of soil erosion on Europe crop yields. Ecosystems, 10, 1209-1219.

Barbier, E. (1990). The farm-level economics of soil conservation: the uplands of Java. Land Economics, 66(2), 199-211.

Berthol, I., Mello, E.L., Guadagnin, J.C., Zaparolli, A.L.V., \& Carrafa, M.R. (2003). Nutrients losses by water erosion. Science Agricola, 60(3), 581-586.

Bidogeza, J.C. (2007). Multivariate typology of farm households based on socio-economic characteristics explaining adoption of new technology in Rwanda. AAAE Ghana Conference Proceedings, 275-278.

Bing, H., Wu, Y., Liu, E., \& Yang, X. (2013). Assessment of heavy metal enrichment and its human impact in lacustrine sediments from four lakes in the mid-low reaches of the Yangtze River. Journal of Environmental Sciences, 25(7), 1300-1309.

Bizoza, A. (2011). Farmers, institutions and land conservation. [PhD thesis], Wegeningen University, Wegeningen, Dutch.

Bizoza, A.R., \& De Graaff, B.A. (2012). Financial cost-benefit analysis of bench terraces in Rwanda. Land Degradation \& Development, 23, 103-115.

Bonda, F., Mlava, J., Mughogho, M., \& Mwafongo, K. (1999). Recommendations for future research to support erosion hazard assessment in Malawi. [Report]. University of Malawi, Malawi.

Bradford, J., \& Huang, L. (1993). Comparison of inter-rill soil loss for laboratory and field procedures. Soil Technology, 6(2), 145-156.

Calfoforo, J.S., Sang, K.P., Luisa, C., Pyne, M.A., Konig, K.W., Malmer, A., ... Sharma, B. (2009). Rainwater harvesting: A lifeline for human well-being. [Report]. United Nations Environment Programme, Nairobi, Kenya.

Christoffel, D.B., Rattan, L., Kieth, W., \& Vince, B. (2000). Impacts of soil erosion on crop yields in North America. Advances in agronomy, 72, 1-50.

Colby, B. (1957). Relationship of unmeasured sediment discharge to mean velocity. Transactions, American Geophysics Union, 38(5), 708-717.

Debebe, W., Melaku, K., Menfese, T. \& Tesfaye, G. (2013). Farmers perceptions and participation on mechanical soil and water conservation techniques in Kembata Tembaro zone: the case of Kachabirra Woreda, Ethiopia. International Journal of Advanced Structures and Geotechnical Engineering, 2(4), 118-131.

DeVere, B.L. (2010). Agri-science fundamentals and applications (5ed). Delmar Cengage Leaning. Clifton Park, USA.

El-Swaify, S., Dangler, E., \& Armstrong. C. L. (1982). Soil erosion by water in the tropics. [Report]. University of Hawaii. Honolulu, Hawaii. 
FAO (1979). The state of food and agriculture. Food and Agriculture Organization of the United Nations, Rome, Italy.

FAO (2000). Manual on Integrated soil management and conservation practices. Food and Agriculture Organization of the United Nations, Rome, Italy.

FAO (2019). Soil erosion: the greatest challenge for sustainable soil management. Food and Agriculture Organization of the United Nations, Rome, Italy.

Farayi, D. (2011). Spatial soil erosion hazard assessment and modelling in Mbire District, Zimbabwe: Implications for catchment management. [MSc thesis]. University of Zimbabwe, Mbire.

Fiener, P., \& Auerswald, K. (2003). Effectiveness of grassed waterways in reducing runoff and sediment delivery from agricultural watersheds. Journal of Environmental Quality, 8, 548-559.

Franz, E.P., Poala, F., Nuna, A., \& Maria C. M. M. (2018). Performance evaluation of soil erosion control by geotextile materials on road cut slope. The 2018 world congress on Advances in Civil, Environmental, \& Materials Research (ACEM18). Sangdo convensia, August 27-31. Incheon, Korea.

Goudie, A. (2000). The human impact on the soil ( $7^{\text {th }}$ ed.). Wiley-Blackwell. Toronto, Canada.

Gray, D.H., \& Leiser, A.T. (1982). Biotechnical slope protection and erosion control. Krieger Publishing Company. Malabar, Florida.

Guo, S., Zhu, Z. \& Lyu, L. (2018). Effects of climate change and human activities on soil erosion in the Xihe river basin, China. Water, 1085, 1-14; doi:10.3390/w10081085.

IWRM (2016). Feasibility study and detail design of the early implementation project on Sebeya catchment. [Report]. Ministry of Natural Resources. Kigali, Rwanda.

Joyce, S. (1998). Major Issues in miner health. Environmental Health Perspectives, 106(11), 538-543.

Julien, P.Y. (2011). Erosion and sedimentation. Geological Magazine, 148(4), 683-684.

Kassa, Y., Beyene, F., Haji, J., \& Legesse, B. (2013). Impact of integrated soil and water conservation program on crop production and income in West Harerghe zone, in Ethiopia. International Journal of Environmental Monitoring and Analysis, 1(4), 111-120.

Kuypers, H., Mollema, A., \& Topper, E. (2005). Erosion control in the tropics (6th ed.). Agromisa Foundation. Wageningen, Netherland.

Laksni, S., Suhardjorno, S., Ery, S., \& Mohammad, S. (2017). Runoff velocity behaviour on smooth pavement and paving blocks surfaces measured by a tilted plot. Journal of water and Land Development, 33(4-6), 149-156.

Lal, R. (1994). Soil erosion research methods (2 ${ }^{\text {nd }}$ edition). Soil and Water Conservation Society, Iowa, USA.

Lal, R. (2001). Soil degradation by erosion. Land degradation \& Development, 12, 519-539.

Landgale, G.W., West, L.T., Bruce, R.R., Miller, W.P., \& Thomas, A.W. (1992). Restoration of eroded soil with conservation tillage. Soil Technology, 5, 81-90.

Liu, X.B., Zhang, X.Y., Wang, Y.X., Sui, Y.Y., Zhang, S.L., Herbert, S.J., \& Ding, G. (2010). Soil degradation: a problem threatening the sustainable development of agriculture in Northeast China. Plant Soil Environ, 56 (2), 87-97.

Littleboy, M., Cogle, A.L., Smith, G.D., Rao, K.P.C., \& Yule, D.F. (1996). Soil management and production of alfisols in the semi-arid tropics. Australian Journal of Soil Research, (34), 127-138. 
Lu, R.S., Lo, S.L., \& Hu, J.Y. (1999). Analysis of reservoir water quality using fuzzy synthetic evaluation. Stochastic Environmental Research and Risk Assessment, 13, 327-336.

Madhu, S. (2008). Rainfall energy loss model in soil erosion process. [PhD Thesis]. University of West Sydney, Sydney.

Matthew, J.H., Thomas, I., Michael, D., Seth, D., \& Jeffrey, S. (2007). Buffers and vegetative filter strips. [Report]. Iowa State University. Iowa, USA.

Mgbenka, R.N., Nicholas, O., Igbokwe, E.M., \& Felix, E. (2012). Soil and water conservation capabilities among farmers and extension agents in Eastern region of Nigeria. African Journal of Agricultural Research, 7(1), 58-67.

MINAGRI (2009). Strategic plan for the transformation of agriculture in Rwanda Phase II. [Report]. Ministry of Agriculture. Kigali, Rwanda.

Morgan, R.P.C. (2005). Soil erosion and conservation ( $3^{r d}$ ed.). Blackwell Publishing. Victoria, Australia.

Morgan, R.P.C., Morgan, D.D.V., \& Finney, H.J. (1984). A predictive model for the assessment of soil erosion risk. Journal of Agricultural Engineering Research, 30, 245-253.

Morris, G., \& Fan, J. (1998). Reservoir sedimentation handbook. McGraw-Hill. New York, USA.

Munyaneza, O., Majoro, F., Mutake, S., \& Hagenimana, E. (2015). Performance evaluation of sediment basins: Case study of Keya hydropower plant in Rwanda. Journal of Water Resource and Protection, 7, 1388-1398.

Munyaneza, O., Majoro, F., Hagenimana, E., \& Usabyisa, W. (2016). Impact assessment of hillside rainwater harvesting ponds on agriculture income: Case study of Ntarama sector in Rwanda. Journal of Water Resource and Protection, 8, 844-854.

Narendar, M.K., Ramavtar, G., Prabhat, T., \& Prashant, S. (2017). Nutrient losses in soil due to erosion. Journal of Pharmacognosy and Phytochemistry, 1, 1009-1011.

Nearing, M., \& Pruski, F. (2004). Expected climate change impacts on soil erosion rates. Journal of Soil and Water Conservation, 59(1), 43-49.

Okoba, O.B., \& De Graaff, J. (2005). Farmers knowledge and perceptions on soil erosion and conservation measures in the Central Highlands, Kenya. Land Degradation \& Development, $16,475-487$.

Pan, C., \& Shangguan, Z. (2006). Runoff hydraulic characteristics and sediment generation in sloped grass plots under simulated rainfall conditions. Journal of Hydrology, 331, $178-185$.

Patil, S.S., Kelkar, T., \& Bhalerao, S.A. (2013). Mulching: a soil and water conservation practice. Agriculture and Forestry Sciences, 1(3), 26-29.

Peng, C., Yonggang, G., \& Yongming, L. (2011). Soil erosion and sediment control effects in the three gorges reservoir region, China. Journal of Resources and Ecology, 2(4), 289-297.

Pimentel, D., \& Kounang, N. (1998). Ecology of soil erosion in ecosystems. Ecosystems, 1, 416-426.

Pimentel, D. (2006). Soil erosion: A food and environmental threat. Environment Development and Sustainability, 8, 119-137.

Pimentel, D., \& Michael, B. (2013). Soil erosion threatens food production. Agriculture, 3, 443-463. 
Pravat, K. S., Ramkrishna, M., \& Gouri, S. B. (2013). Assessing the performance of check dams to control rill-gully erosion: Small catchment scale study. International Journal of Current Research, 5(4), 899-906.

Renard, K., Foster, G.R., Weesies, G.A., McCool, D.K., \& Yoder, D.C. (1997). Predicting soil erosion by water: A guide to conservation planning with the Revised Universal Soil Loss Equation (RUSLE). USDA-United State Department of Agriculture. Washington DC, USA.

Robinson, D., \& Phillips, C. (2000). Crust development in relation to vegetation and agriculture practice on erosion susceptible, dispersive clay soils from Central and Southern Italy. Soil and Tillage Research, 60, 1-9.

Sakinatu, I., \& Muhammad, A. (2017). Impact of soil erosion and degradation on water quality: a review. Geology, Ecology and Landscapes, 1(1), 1-11.

Saleem, Y.S., Zahoor, U.I., \& Shakeel, A.R. (2018). Engineering feasibility of gabion structures over reinforced concrete structures. International Research Journal of Engineering and Technology, 5(10), 990-994.

Savadogo, P., Bayala, J., \& Kalinganire, A. (2017). Restoration of degraded lands in Mali: a review on lessons learnt and opportunities on scaling. [Report]. European Commission. Bamako, Mali.

Schwertmann, U., Nill, D., Sabel-Koschella, U., Bernhard, M., \& Breuer, J. (1996). Soil erosion by water in Africa. GTZ. Posrfach, Germany.

Shahzeidi, S.S., Entezari, M., Gholami, M., \& Dadashzadah, Z. (2012). Assessment rate of soil erosion by GIS (Case study Varmishgan, Iran). Journal of Basic and Applied Scientific Research, 2(12), 13115-13121.

Solomon, B. (2016). Assessment of factors that determine farmers adoption behaviour of soil and water conservation practice in Libo Kemkem Woreda, Ethiopia. [MSc thesis]. AddisAbaba University. Addis-Ababa, Ethiopia.

Syvitski, J.P., Smarty, J.V., Kettner, J.A. \& Pamela, G. (2005). Impact of humans on the flux of terrestrial sediment to the global coastal ocean. Science, 308, 376-380.

Troxel, C.F. (2013). Life cycle analysis of sediment control devices. [MSc thesis]. Georgia Institute of Technology. Atlanta. USA.

Van, T.T., Dafang, F., Tran, N.B., Eldon, R.R., Tang, T.T.S., \& Rajendra, P.S. (2018). An Investigation on performance and structure of ecological revetment in a sub-tropical area: A case study on Cuatien river, Vinh City, Vietnam. Water, 636(10), 1-18.

William, P. A. (1997). Massachusetts erosion and sediment control guidelines for urban and suburban areas. Department of Environmental Protection. Massachusetts, USA.

Williams, J. R. (1975). Sediment routing for agricultural watersheds. Journal of the American Water Resources Association, 11(5), 965-974.

Wilson, G.V., Cullum, R. F., \& Romkens, M. J.M. (2008). Ephemeral gully erosion by preferential flow through a discontinuous soil-pipe. Catena, 73, 98-106.

Wischmeier, W., \& Smith, D. (1978). Predicting Rainfall Erosion Losses. U.S Department of Agriculture. Washington D.C, USA.

Zhai, K. (2010). Reservoir water quality assessment based on Fuzzy evaluation method. Journal of Hubei University for Nationalities, 28, 10-12.

Zhang, D., Richard, M.G., \& Tan, S.K. (2009). Constructed wetland in China. Ecological Engineering, 35, 1-10. 
Zuazo, V., \& Rogriguez, C. (2008). Soil erosion and runoff prevention by plant cover: A review. Agronomy for sustainable development, 28(1), 65-86. 